\title{
O succintă prezentare a luării aminte de sine la Sfântul Vasile cel Mare
}

\author{
Laurnețiu-Sorin ORMENIȘAN*
}

Abstract: Saint Basil the Great is among the first filocalic parents who establishes the bridge between Greek philosophy and Christianity, understood as the highest philosophy. One of the terms that was taken from the Greek philosophical terminology by the great hierarch is attentiveness to itself, which makes one person attentive to each moment of his life. The purpose of this attentiveness is to bring men to deepen itself, where he will be able to discover the "kingdom of God" cf. Luke 17.19.

Keywords: attentive to itself, prosoche, Saint Basil the Great, Greek philosophy

\section{Introducere}

În societatea de astăzi, atenția ne este bombardată cu informații venite din toate părțiile, de la simplele pliante până la campanii

* PhD Candidate, Faculty of Orthodox Theology at "1 Decembrie 1918” University in Alba Iulia, Romania. 


\section{Laurnețiu-Sorin ORMENIȘAN}

zgomotoase de prezentări și promovări media. Toate au scopul, nu doar de atrage atenția ci și de a lua aminte la anunțul prezentat. Suntem atât de asaltaţi de toate aceste lucruri încât nu mai putem să fim atenți la lucrurile care necesită atenția și care sunt socotite importante. Atenția (prosoche, gr.) despre care amintește și Sfântul Vasile cel Mare, este unul dintre punctele importante pe care le promovează atât în omiliile sale cât și în scrierile ascetice. Astfel că atenția la care se referă marele ierarh în lucrările sale, nu poate fi alta decât cea la sine însuși, înțeleasă ca și grijă, prudență, vigilență față de sine.

Scopul acestei luări aminte este acela de al face pe om să se adâncească în sine, acolo unde ne-a promis și Mântuitorul că este, ,înlăuntrul nostru”(Luca 17,21). Asupra luării aminte marele ierarh capadocian i-a dedicate o omilie pornind de la versetul biblic: „Ia aminte la tine însuți, ca nu cumva un cuvânt ascuns în inima ta să se prefacă în păcat"'(Deut. 15,9). Marele ierarh, pornind de la referatul biblic, face o întreagă apologie asupra lui prosoche, ținând seama că termenul era unul de proveniență tehnică din filozofia antică². Această atitudine de atenție asupra sinelui, este specifică filosofiei antice, îndeosebi stoicilor și platonicienilor. Pentru aceștia, grija lor era aceea de neîntreruptă trezvie. Omul trăind această stare devenea conștient de locul său în univers și de legătura cu Dumnezeu. ,Această conștiință de sine, este înainte de toate, o conștiință morală, care va urmări constant să împlinească o purificare și o îndreptare a intenției; ea veghează ca nici o faptă să nu fie înfăptuită pe o altă rațiune, decât pe voinţa de a face binele. Însă această conștiință de sine nu are doar caracterul de conștiință morală ci ea este și o conștiință cosmică: omul «atent» trăiește permanent în prezența lui Dumnezeu, consimțind cu bucurie la voința Rațiunii universale și privind toate lucrurile cu

\footnotetext{
${ }^{2}$ Pierre Hadot, Exercices spirituels et philosophie antique, Douxième édition revue et augmentée, Études augustiniennes, Paris, 1987, p. 64 / Exerciții spirituale și filozofie antică, Traducere din limba franceză de Pr. Constantin Jinga, Postfață de Ierom. Agapie Corbu, Arad, Editura Sfântul Nectarie, 2015, p. 91.
} 
privirea lui Dumnezeu Însuși”’3.

Împăratul-filozof Marcus Aurelius, vorbind despre atenția la sine, spune că: ,astfel să acționezi, să exprimi și să gândești fiecare lucru, ca și cum ai putea să părăsești chiar în această clipă viața"'. Concentarea asupra prezentului, dar mai ales asupra clipei, dovedește controlul asupra gândurilor, dar și starea de acceptare a voinței divine și purificare a intențiilor în relația cu aproapele. În acest fel spune împăratul-filozof: „totdeauna și în orice loc, depinde de tine să fi mulțumit, cu pietate, de împrejurările prezente, și să te porți conform dreptății față de oamenii prezenți în jurul tău, și să-ți aplici, în slujba reprezentării prezente, toate regulile discernământului, ca să nu se strecoare nimic care să nu fie o reprezentare adevărată"s.

Pentru neoplatocianul Porfir, atenția la sine, echivala cu luarea aminte de a fi mereu în prezența lui Dumnezeu. ,în orice faptă, în orice lucrare, în orice cuvânt, fie ca Zeul să fie prezent, ca martor și ca păzitor". Unul dintre sensurile lui prosoche, pe care îl prezintă constant filosofii, este acea prezență în raport atât cu divinitatea cât și cu sinele. „Într-un singur lucru găsește-ți desfătarea și odihna: trecerea de la o acțiune în interesul semenilor, la o alta în interesul semenilor, aducându-ți aminte de Zeu"’.

Înainte de Sfântul Vasile, Sfântul Clement Alexandrinul a anticipat importanța luării aminte de sine, care va deveni dominant în cadrul monahismului de inspirație filocalică ${ }^{8}$. „Mi se pare că asta e pricina că legea cea dumnezeiască a atârnat în chip necesar deasupra capetelor noastre frica, pentru ca filosoful prin temerea de Dumnezeu

${ }^{3}$ Ibidem, p. 63 [în română a se vedea p. 89.]

${ }^{4}$ Marcus Aurelius, Gânduri către sine însuși, Traducere de Cristian Bejan, București, Editura Humanitas, 2013, p. 89.

${ }^{5}$ Ibidem, p. 221.

${ }^{6}$ Porfir, Epistula ad Marcellam, §12, p. 18. 10 Pötscher apud. Pierre Hadot, op. cit., p. 66 / în rom. p. 95.

${ }^{7}$ Marcus Aurelius, op. cit., p. 175.

${ }^{8}$ Pierre Hadot, op. cit., p. 63 / în rom. p. 89-90. 
și luare - aminte, să dobândească liniștea sufletească, și s-o păstreze, rămânând în toate împrejurările vieții desăvârșit și fără de păcat"”.

Marele ierarh atrage atenția asupra importanței sufletului în detrimentul trupului în care atenționează, că trebuie să cunoaștem: „,că o parte a sufletului tău rațională și cugetătoare, iar alta, irațională și pătimașă. E firesc ca prima să conducă, iar cealaltă să asculte și să se supună rațiunii ${ }^{10}$. Deci, să nu lași ca rațiunea fiind robită, să ajungă sclava patimilor, dar iarăși, nici să îngădui patimilor să se ridice împotriva rațiunii și să pună stăpânire pe suflet" "1, iar mai departe atenționează „nu te alipi de cele muritoare, ca și cum ar fi veșnice, nici nu disprețui pe cele veșnice, ca și cum ar fi trecătoare. Nu te uita la trup, căci este trecător, ci poartă grijă de suflet, de lucrul cel nemuritor ${ }^{12} \ldots$ dacă ne vom socoti pe noi înșine a fi bogați și de vreun rang mai înalt, ne vom aduce aminte că suntem făcuți din pământ și ne vom întreba unde sunt de-acum cei toți cei vrednici de cinste, care au trăit înaintea noastră. Dacă, dimpotrivă, suntem săraci, și disprețuiți, vom lua aminte la toate bogățiile și splendorile pe care ni le oferă creațiunea: trupul nostru, pământul, cerul, corpurile cerești, și ne vom aduce aminte de vocația noastră dumnezeiască" ${ }^{\prime 13}$.

Titlul accestei omilii se aseamănă cu îndemnul delphic, preluat

${ }^{9}$ Clement Alexandrinul, Stromatele, Scrieri. Partea a doua, în „P.S.B. 5”, traducere de Pr. Dumitru Fecioru, București, Editura Institutului Biblic și de Misiune al Bisericii Ortodoxe Române, 1982, p. 171.

${ }^{10}$ Imaginea este puțin simplificată. De obicei, sufletul avea trei aspecte: mintea sau partea conducătoare, partea apetitivă cuprinde iuțimea sau curajul și partea poftitoare sau pasiunea după cum este amintit în Platon, Republica, IV, 434D-442B; Timaios 69C-70A.

${ }^{11}$ Sfântul Vasile cel Mare, Omilii și cuvântări, în „PSB 1”, ediţia nouă, traducere din lb. greacă și introducere de pr. Dumitru Fecioru, text revăzut și notă asupra ediției de Constantin Georgescu, București, Editura Basilica, 2009, p. 81.

${ }^{12}$ Ibidem, p. 74, din citatul desprins se evidențiază influența Sfântului Vasile cel Mare în imnografie.

${ }^{13}$ Ibidem, p. 82. 
ca motto al vieții filozofului Socrate, $\gamma v \tilde{\omega} \theta l \sigma \varepsilon \alpha v \tau o ́ v^{14}$ „cunoaște-te pe tine însuți". Amândouă îndemnurile vor să atragă atenția asupra omului lăuntric, omul care nu este doar un noian de instincte, ci rațiunea și puterea de a înțelege lumea prin sine însuși, dar și de a descoperi divinitatea prin adâncirea în ființa proprie. Sfântul Vasile cel Mare, vorbind de importanța acestui îndemn, adaugă și acesta: „fiecăruia îi place să se intereseze mai mult de treburile altuia decât de propriile lui griji. Și, ca să scăpăm de acest cusur, porunca spune: Încetează de a te interese de păcatele altuia! Nu mai da răgaz gândurilor, să se ocupe de cusururile altora ci: «Ia aminte de tine însuți», adică: întoarce-ți ochiul sufletului spre cercetarea propriilor cusururi. Da, mulți oameni, după cuvântul Domnului, văd paiul din ochiul fratelui, dar nu văd bârna din ochiul lor (Mt.7,3). Nu înceta deci de a te cerceta pe tine însuţi, ca să vezi dacă viața ta merge după poruncile Domnului"'15. Din adâncirea în cunoașterea de sine, spune ierarhul se va ajunge la cunoașterea lui Dumnezeu: ,dacă iei aminte la tine însuți, nu mai ai nevoie să descoperi pe Creator în celelalte creaturi; vei contempla în tine însuți, ca într-un microcosmos ${ }^{16}$, marea înțelepciune a Creatorului tău"17, iar pentru a nu uita de chemarea lui Sfântul Vasile îndeamnă ca: „după ce ai privit sufletul, privește și alcătuirea trupului lui și admiră ce locaș potrivit a meșteșugit Dumnezeu sufletului rațional. Dintre toate viețuitoarele pe om 1-a creat Dumnezeu cu facultatea de a sta drept ${ }^{18}$. Ca să cunoști, din

\footnotetext{
${ }^{14}$ Expresia $\gamma v \tilde{\omega} \theta l \sigma \varepsilon \alpha v \tau o ́ v$ a fost un îndemn foarte răspândit în cultura antică. ${ }^{15}$ Ibidem, p. 77.

${ }^{16}$ Profesorul Maryanne Cline Horowitz, prezintă ideea microcosmosului ar fi apărut prima dată la filozofii greci precum Pitagora sec. VI î. d. Hr., și Democrit în sec. V. î.d.Hr., ea este dezvoltată la Platon în lucrarea Philebos 28D-30E. Însă

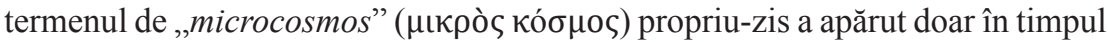
lui Aristotel, Fizica VIII, 2, 252B.26, după cum precizează în lucrarea, New Dictionary of the History of Ideas, Vol. 4, Detroit, Thomson Gale, 2005, p. 1440. ${ }^{17}$ Sfântul Vasile cel Mare, Omilii și cuvântări..., p. 81.

${ }^{18}$ Denumirea de „om”( $\alpha$ $\left.\alpha \theta \rho \omega \pi o \varsigma\right)$ este un derivat din limba greacă de la

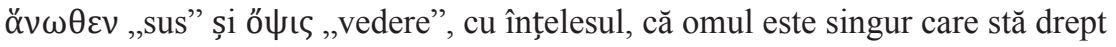


poziția lui, că viața ta este o origine dumnezeiască. Toate patrupedele sunt plecate spre pântece; numai omul are privirea îndreptată spre cer, ca să nu se îndeletnicească cu pântecele, nici cu pasiunile cele de sub pântece, ci să aibă toată pornirea lui spre înălțime"19.

Într-una dintre epistole ${ }^{20}$, Sfântul Vasile îndeamnă pe un tânăr la trăirea cu atenție a vieții creștine, care necesită un exercițiu continuu: „Deprinde-te odată și bagă-ți în urechi rânduielile evanghelice, strunirea deplină a trupului, smerenia cugetului, curăția gândirii, stingerea mâniei! Oricât vei fi de copleșit de treburi, fă-ți și mai multă vreme pentru Domnul; ... dacă ești prigonit, rabdă, dacă ești defăimat, roagă-te; fii mort păcatului, răstignește-te pentru Dumnezeu; aruncăți toată povara grijilor pe spatele Domnului, pentru ca să te afli și tu printre miile de îngeri, tronurile apostolilor, scaunele de cinste ale proorocilor, toiegele patriarhilor, cununile mucenicilor, laudele drepților. Să dorești și tu să te numeri împreună cu cei drepți, în Hristos Iisus, Domnul nostru" ${ }^{21}$. Întreaga noastră viață este o luptă cu patimile și păcatele, care vor să ne înrobească lumii acesteia.

Pentru sfântul ierarh, viața aceasta pământească, care este trecătoare și pentru care vom da răspuns la Judecata de apoi, este pregătire și exercițiu pentru viața viitoare. Lupta deși se duce până la mormânt, bunătățile la care suntem chemați, sunt veșnice: ,acolo, însă, trainice sunt temeliile, viața nu se mai schimbă, nu mai este teama

și privește în sus.

${ }^{19}$ Sfântul Vasile cel Mare, Omilii și cuvântări..., p. 82.

${ }^{20}$ Este vorba despre epistola a 43-a, data exactă nu se cunoaște dar este dinaintea episcopatului, care cuprinde un îndemn către un tânăr. Acest fragment nu este întâlnit în nici un manuscris care cuprinde epistolele Sfântului Vasile. El a fost strâns de călugării maurini în ediția pe care o reproduce și colecția Migne. Autenticitatea ei este discutabilă. Ea nu este propriu-zis o epistolă, ci este mai mult o omilie trunchiată, deși se folosește singularul.

${ }^{21}$ Idem, Epistole, în „PSB 3”, serie nouă, traducere din limba greacă, introducere și note de Pr. Teodor Bodogae, Ediție răvăzută de Tudor Teoteoi, București, Editura Basilica, 2010, pp. 105-106. 
căderii în păcat, nici ațațarea trupului, nici conlucrarea femeii pentru săvârșirea păcatului, pentru că la înviere nu mai este bărbat și femeie (Mt. 22, 30), viața este una și neamestecată, pentru că cei care au bineplăcut Stăpânului lor locuiesc în ținutul celor vii”’22. Dar nu pentru toți, trecerea din lumea aceasta va fi motiv și prilej de bucurie, pentru că în lumea cealaltă se va vădi cu adevărat lucrarea noastră. De aceea e important, ca faptele să fie făcute pentru bunătățile promise după cum amintește ierarhul că: ,,acesta este veacul pocăinței, acela al răsplătirii, acesta al răbdării, acela al mângâierii. Acum Dumnezeu este ajutător celor care se întorc din calea cea rea, atunci va fi cercetător înfricoșător și de neînșelat al faptelor, al cuvintelor și al gândurilor omenești” ${ }^{23}$.

\section{Luarea aminte la suflet}

Trupul este un colaborator al curățirii sufletului, și în acest fel nu se poate spune că numai sufletul contează, pentru că dacă va neglija cu desăvâșire trupul, sufletul se va vătăma de neputințele trupești. Sfântul Vasile cel Mare, care deși pare că neglijează trupul, îi acordă o cinste deosebită, tocmai pentru că știe rolul acestuia în mântuirea omului.

Trupul după cum menționează în omilia adresată tinerilor despre dreapta întrebuințare a scrierilor profane, recomandă și îndeamnă ca acesta să fie slujit numai cât îi sunt necesare cele de trebuință, iar sufletului trebuie dat ceea ce este mai bun, adică înțelepciunea. Iar aceasta nu este doar o noțiune abstractă ci reprezintă grija și luarea aminte la suflet prin dobândirea virtuților.

Sfântul Vasile cel Mare după o viață de nevoință și asceză, recomanda nu doar tinerilor ci tuturor oamenilor ferirea trupului

\footnotetext{
${ }^{22}$ Idem, Scrieri dogmatice și exegetice, în „PSB 4”, serie nouă, traducere din limba greacă de Ierom. Policarp Pîrvuloiu și Pr. Dumitru Fecioru, București, Editura Basilica, 2011, p. 578.

${ }^{23}$ Idem, Scrieri morale și ascetice, în „PSB 5”, serie nouă, Studiu introductiv de Pr. Vasile Răducă, Traduceri de Isabela Alina Panainte, Florin Filimon, Laura Enache, Octavian Gordon, Diac. Nicolae Mogage, Bucureşti, Editura Basilica, 2013, pp. 618-620.
} 


\section{Laurnețiu-Sorin ORMENIȘAN}

de diferite tentații, care duc în rătăcire. Grija permanentă de trup dovedește o persoană care nu a înțeles că omul nu este doar ceea ce se vede. Continuând cu același raționament, spune că cei care s-au subjugat trupului, prin diferite plăceri trupești, și care s-au dedat pentru a deveni bogati sunt într-o stare nefirească, pentru că adevărata bogăție și podoabă a omului este virtutea, care nu doar că nu rușinează, ci ea rămâne și după moarte.

Limbajul uneori sever împotriva trupului din scrierile ascetice este mai atenuat în omiliile sale ${ }^{24}$. Faptul că omul are o valoare deosebită, este dovedită de marele ierarh prin crearea omului față de celelalte zidiri. Despre nici o altă creație a lui Dumnezeu nu se spune că este făcută după Chipul Dumnezeului Celui Preaînalt. Deosebirea dintre suflet și trup este asemănată cu cea dintre cer și pământ. Sufletul reprezintă cerul, pentru că acolo locuiește Dumnezeu, iar trupul este din pământ unde locuiesc toate lucrurile muritoare ${ }^{25}$.

Omul prin cunoașterea de sine va ajunge la cunoașterea lui Dumnezeu, pentru că poate admira în el, marea lucrarea a Ziditorului. Dumnezeu poate fi admirat și pentru că în fiecare există o unitate a sufletului cu trupul. Legătura dinte suflet și trup arată o unitate și comunicare, prin aceea că trupul primește viață de la suflet, iar trupul ii dă dureri sufletului: „Sufletul își pierde propria frumusețe dacă alunecă spre patimile trupului, și iarăși dacă se curăță de urâțenia pricinuită de viciu, se înalță prin virtute la asemănarea cu Creatorul'”26.

Se poate observa, că din toate argumentele interne ale operei vasiliene, marele ierarh arată prioritatea slujirii sufletului, față de trup. Cel care se îngrijește doar de problemele trupești arată că nu se cunoaște pe sine. Cum se poate recunoaște un om trupesc? Prin grija manifestată de problemele trupești, iar astfel de oameni îl vor lăuda

\footnotetext{
${ }^{24}$ Arhid. Prof. Dr. Constantin Voicu, Studii de teologie patristică, București, Editura I.B.M.B.O.R., 2004, p. 204.

${ }^{25}$ Sfântul Vasile cel Mare, Scrieri morale și ascetice..., p. 549.

${ }^{26}$ Idem, Omilii şi cuvântări..., p. 81.
} 
pe Dumnezeu când se vor afla în împrejurări bune ${ }^{27}$ lipsiți de boli, și Îl vor osândi atunci când vor înfrunta greutăți și necazuri.

Chiar dacă pare că sufletul și trupul ar fi a două entități diferite, în om, totuși ei sunt un tot unitar, în care fiecare trebuie să se îngrijească de celălalt. Insă Sfântul Vasile atrage atenția mereu în cuvintele sale, asupra efemerității existenței trupești și corporale. $\mathrm{Cu}$ cât sunt satisfăcute și împlinite simțurile trupești cu atât ele vor cere mai mult și se vor răzvrăti împotriva sufletului, ajungând dacă omul nu va mai trăi decât prin simțuri doar la satisfacerea necesătăților fiziologice și a instinctelor.

\section{Luarea aminte la virtute}

Virtutea este la Sfântul Vasile atât condiția cât și mijlocul principal pe care trebuie să o câștige credinciosul pentru a se numără în împărăția drepților. Sfântul Vasile a fost influențat de concepția raţionalistă a culturi antice asupra virtuții, care reprezenta o știință, după cum a susținut atât Socrate cât și ucenicul acestuia, Platon. Sfântul Vasile a unit începutul virtuții de ,cercetarea stăruitoare”

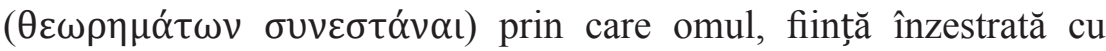
rațiune, este capabilă să deosebească binele de rău, și să găsească calea pe care trebuie să o urmeze în vederea desăvârșirii. Pe de altă parte Sfântul Vasile ne amintește și de concepția aristotelică asupra virtuții, după care, ea este calea de mijloc dintre două extreme, la fel de primejdioasă oricare dintre acestea. Calea de mijloc poate fi găsită cu ajutorul rațiunii, astfel că Sfântul Vasile spune că: „Virtutea este urmarea unui lung proces de deliberare asupra conduitei pe care o urmează să o îmbrățișăm în fața unei probleme morale care ni se pune" ${ }^{28}$. Ea se realizează printr-o lungă stăruință, însă pentru

\footnotetext{
${ }^{27}$ Idem, Scrieri dogmatice și exegetice..., p. 531.

${ }^{28}$ Idem, Omilia despre invidie, în (PG XXXI, 372-385) trad. în limba română de Teodor M. Popescu, Două omilii ale Sfântului Vasile cel Mare, București, 1936, p. 47.
} 


\section{Laurnețiu-Sorin ORMENIȘAN}

dobândirea ei este necesar ca omul să folosească capacitatea sa naturală de discernere a binelui de rău. Spune sfântul ierarh, despre cel care s-a deprins cu exercițiul virtuții, alegând binele și respingând răul, a devenit posesorul virtuții, care nu este doar o podoabă a celui care o are ci și o forță care îl ajută să lucreze numai binele, fără eforturi deosebite. Prin această concepție Sfântul Vasile depășește concepția intelectualistă asupra virtuții, care susține că virtutea este doar o deprindere ${ }^{29}$ în săvârșirea binelui.

Se pare că în concepția Sfântului Vasile, unul dintre izvoarele

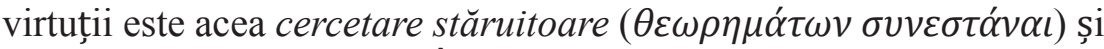
exerciţiul de a face binele. Însă pentru ca și creștinul să dobândească virtutea este nevoie și de harul dumnezeiesc prin care se câștigă discernământul, dar și statornicia în săvârșirea binelui. Astfel nu se va mai considera un efort împlinirea virtuții, ci un lucru normal, firesc cu care s-a obișnuit. Prin acest fel de viețuire și prin împreună lucrarea cu harul lui Dumnezeu, se ajunge la armonia dintre gând și faptă, care face ca omul să fie curățit de orice intenție rea și influențând și pe alții prin exemplul său personal.

\section{Luarea aminte la efortul ascetic}

Pentru Sfântul Vasile, efortul ascetic, se întărește atât prin efortul personal, cât și prin grija de a îndemna pe credincioși la o astfel de viață. Sfântul Vasile de când și-a conștientizat chemarea, a fost atras de viața de nevoința pentru dobândirea mântuirii. Într-una dintre epistolele vasiliene, marele ierarh, sublinia dorul după Dumnezeu prin nevoință, mai ales după ce a mers în mai multe pelerinaje în Egipt, Mesopotamia, Palestina, unde a întâlnit mulți părinți, care se nevoiau prin înfrânarea de la mâncare și băutură, prin râvnă la rugăciune s-au făcut modele vii pentru marele ierarh, care: „văzând

\footnotetext{
${ }^{29}$ Arhid. Ioan Zăgrean, Probleme morale în opera Sfântului Vasile cel Mare, în „Studia Basiliana”, vol. I, Ediția a II-a revăzută, adăugită și îngrijită de Emilian Popescu și Adrian Marinescu, București, Editura Basilica, 2009, pp. 340-341.
} 
cum înlătură somnul și cum își impun să se abțină de la orice poftă a firii, păstrându-și în toată vremea mintea slobodă și înălțată deasupra patimilor, în foame și sete, în frig și golătate, fără să poarte grijă de trup și fără să se gândească prea mult la el, lăsându-mi impresia că ar petrece într-un trup străin, ca și cum și-ar avea cetățenia în cer. Și tot minunându-mă de aceste lucruri și fericind într-una viața acestor oameni, încât ei arătau tot timpul în trup, omorârea lui Iisus (II Cor., 4, 10), mi-am dorit din toată inima să pășesc și eu pe urmele lor cât îmi stă în putință" ${ }^{30}$.

Luarea aminte la sine reprezintă unul dintre punctele fundamentale a filosofiei antice dar și unul dintre liantele de trecere în creștinism, îndeosebi în monahism, loc unde a prins alte înțelesuri și profunzimi.

\section{Bibliografie:}

1. Alexandrinul, Clement, Stromatele, Scrieri. Partea a doua, în,P.S.B. 5", traducere de Pr. Dumitru Fecioru, București, Editura Institutului Biblic și de Misiune al Bisericii Ortodoxe Române, 1982.

2. Aurelius, Marcus, Gânduri către sine însuși, Traducere de Cristian Bejan, București, Editura Humanitas, 2013.

3. Hadot, Pierre Exercices spirituels et philosophie antique, Douxième édition revue et augmentée, Études augustiniennes, Paris, 1987, p. 64 / Exerciții spirituale și filozofie anticăa, Traducere din limba franceză de Pr. Constantin Jinga, Postfață de Ierom. Agapie Corbu, Arad, Editura Sfântul Nectarie, 2015.

4. Horowitz, Maryanne Cline, New Dictionary of the History of Ideas, Vol. 4, Thomson Gale, Detroit, 2005.

5. Vasile, Sfântul cel Mare, Omilii și cuvântări, în „PSB 1”, ediția nouă, traducere din $\mathrm{lb}$. greacă și introducere de pr. Dumitru Fecioru, text revăzut și notă asupra ediției de Constantin Georgescu, București, Editura Basilica, 2009.

6. Idem, Scrieri dogmatice și exegetice, în „PSB 4”, serie nouă,

${ }^{30}$ Idem, Epistole...op. cit., p. 352. 
traducere din limba greacă de Ierom. Policarp Pîrvuloiu și Pr. Dumitru Fecioru, București, Editura Basilica, 2011.

7. Idem, Epistole, în „PSB 3”, serie nouă, traducere din limba greacă, introducere și note de Pr. Teodor Bodogae, Ediție răvăzută de Tudor Teoteoi, București, Editura Basilica, 2010.

8. Idem, Scrieri morale și ascetice, în „PSB 5”, serie nouă, Studiu introductiv de Pr. Vasile Răducă, Traduceri de Isabela Alina Panainte, Florin Filimon, Laura Enache, Octavian Gordon, Diac. Nicolae Mogage, Bucureşti, Editura Basilica, 2013,

9. Idem, Omilia despre invidie, în (PG XXXI, 372-385), trad. în limba română de Teodor M. Popescu, Două omilii ale Sfântului Vasile cel Mare, București, 1936.

10. Voicu, Arhid. Prof. Dr. Constantin, Studii de teologie patristică, București, Editura I.B.M.B.O.R., 2004.

11. Zăgrean, Arhid. Ioan, Probleme morale în opera Sfântului Vasile cel Mare, în „Studia Basiliana”, vol. I, Ediția a II-a revăzută, adăugită și îngrijită de Emilian Popescu și Adrian Marinescu, București, Editura Basilica, 2009. 